\title{
Fiduciary duty, statute, and pension fund governance: the search for a shared conception of sustainable investment
}

\author{
Gordon L Clark, School of Geography and the Environment, Oxford University, \\ Hinshelwood Rd., Oxford OX1 3QY, UK and Faculty of Business and Economics, \\ Monash University, Caulfield VIC 3145, Australia.
}

\section{Contact.gordon.clark@ouce.ox.ac.uk}

\begin{abstract}
Fiduciary duty is the golden rule 'regulating' the relationship between trustees and beneficiaries. In principle, it regulates behaviour by pre-empting those actions that would harm the interests of beneficiaries while promoting duties of care consistent with the interests of those that stand to gain from well-intentioned and responsible decision-making. But, in many respects, fiduciary duty is a chimera: it looks to convention rather than forward to innovation in investment management. As such, governance policies and practice must provide the instruments that simple recipes of fiduciary duty are ill-equipped to provide. In this paper, I argue that the design and governance of investment management institutions is, actually, more important than honouring the principle fiduciary duty which, in the context of Anglo-American statute, is increasingly empty. In doing so, I re-read the classic cases that define the principle while identifying the problems which the golden rule has been unable to resolve. This is the back-drop for reconsidering the virtues or otherwise of a governance-focused regulatory regimes. In the penultimate section of the paper I focus on the mechanisms currently used to cultivate a regulatory regime that is at once long-term oriented and responsive to the climate change challenge that confronts humanity.
\end{abstract}

Keywords. Fiduciary duty, common law, governance, statute, long-term investment

JEL Codes. G23, G38, K42, O16

Acknowledgements. This paper draws its inspiration from ongoing conversation with Claire Woods about the nature and character of fiduciary duty in Anglo-American investment management and our collaboration with Roger Urwin on the principles and practice of the governance of financial institutions, including endowments, pension funds, and sovereign wealth funds. The paper was presented at the UN PRI Conference co-sponsored by MISTRA in Stockholm 2011 and is the first instalment for the Social Science and Humanities Research Council of Canada sponsored CommunityUniversity Research Alliance on 'Responsible Investing' led by Tessa Hebb of Carleton University (Ottawa). In writing the paper, I have drawn upon my collaboration, past and present, with friends and colleagues including Adam Dixon, Dorothee Franzen, Ashby Monk, and Dariusz Wójcik. Finally, I benefitted from discussion with Shlomit Wallerstein on the issue of the common law and fiduciary duty while Olga Thönissen and Christina Ender provided expert research assistance. Reflections on these issues have been informed by my involvement with MetallRente and my role as a trustee of the Oxford Staff Pension Scheme. None of the above should be held responsible for the views and opinions expressed herein, which are entirely my own. 


\section{Introduction}

Economic historians charting the rise of agrarian capitalism, the industrial revolution, and the modern corporation argue the liberation of capital from its past was a vital ingredient in British economic development (Maitland 1905). More generally, King and Levine (1993a, 1993b), drawing upon 20th century experience, show that the rate of economic development is dependent upon the scope and sophistication of nation-states' capital markets. With respect to variations between financial markets, La Porta et al. $(1997,1998)$ suggested that the liquidity and importance of nations' stock markets is owed, in large part, to their legal traditions and whether those traditions are consistent with market efficiency, empowering third parties such as fiduciaries to allocate capital between competing opportunities. For Hawley and Williams (2001), the common law tradition of fiduciary duty has had profound implications for the economic and financial structure of AngloAmerican economies.

The trust is a means of conserving and transferring assets to nominated beneficiaries (Langbein 1997). It also enables intermediaries to represent the interests of beneficiaries, providing the former with authority to invest on behalf of the latter. Regulating the behaviour of trustees, the principle of fiduciary duty governs the relationship between trustees and beneficiaries (Thomas and Hudson 2004, Sec. 1.56). There are a variety of definitions of this principle ranging from the abstract through to the domain-specific. Atiyah $(1995,255)$ observed that a fiduciary relationship binds trustees to beneficiaries such that "the person in the fiduciary position is under a duty not to abuse that position, and this duty involves the duty to disclose all material facts." Stapleton $(1996,13)$ noted, in relation to company directors and senior executives, being a fiduciary also involves "honesty and loyalty, and a duty of care and skill." Langbein $(2007,1075)$ observed the "core fiduciary principle" ... "is the duty of impartiality"; a rule conceived and policed so as to 'regulate' conflicts of interest. ${ }^{1}$

The paper begins with the historical significance of fiduciary duty. This allows us to understand fiduciary duty in relation to functionally efficacious common law norms and conventions; whereas some might suggest that fiduciary duty evolved as the standard of behaviour because of its effectiveness in maximising social welfare, it is important to acknowledge the idealism about past communities of practice, which is embedded in such claims. This is followed by a re-reading of two landmark cases that effectively defined the nature and scope of fiduciary duty, relevant to

\footnotetext{
1/. Notice, however, impartiality need not require trustees to act for the "exclusive" benefit of beneficiaries. It may be sufficient to act in their "best" interests especially if trustees have access to investment expertise and opportunities by virtue of their separate but related professional activities (Langbein 2005).
} 
investment management. I suggest that whatever its' ideal conception, it has proven insufficient as the golden-rule governing the trust institution (Clark 2006). Government policies designed to define and regulate the governance of the trust institution represent attempts to solve problems evident in the practice of investment.

Whereas explanations of common law doctrine typically refer to community norms and conventions, the very idea of commonly-shared norms and conventions has been undercut by moral pluralism and contestation over basic values (Clark 1985). Indeed, so pervasive is dispute over the nature and scope of fiduciary duty that it is tempting to re-read the doctrine so as to pull apart idealism about the past. As indicated below, the evidence suggests that community norms and conventions have been suborned by powerful interests that use the rhetoric of fiduciary duty to advance their own causes. Just as Alan Greenspan's idealism about the social value of rational self-interest was brought asunder by the global financial crisis (Clark 2011), it would seem that the moral imperatives of individual reputation and community standing are not effective in sustaining the authority of fiduciary duty (compare Braithwaite 1989). These norms have wilted in the face of contests for control over the investment management process.

My argument about the nature and significance of fiduciary duty in relation to government regulation treats both as 'solutions' to problems associated with the preservation and management of financial assets. It has a decidedly functionalist character (see also Merton and Bodie 2005). As such, it has a rather different ontology than claims to the effect that fiduciary duty has some fundamental significance in that it represents core values and commitments of Anglo-American societies. My argument disparages idealism in the face of historical contingency: nonetheless, my argument may be thought beside the point; that is, the degradation of a principle does not ipso facto deny its purity and, in fact, provides a rationale for the re-assertion of its significance against those that would discount its relevance. This is a plausible strategy of resistance. But, in my view, practice trumps theory. ${ }^{2}$ Resistance is to be understood as a rhetorical gesture (Runciman 2008).

Notice, however, I am not entirely optimistic about the value of government regulation 'standing-in' for fiduciary duty. Realist conceptions of the formation and passage of statute provide many lessons

\footnotetext{
\%. This statement draws its inspiration from Wittgenstein (1968) and Fish $(1980,14)$ amongst others. Fish argues that the meaning of concepts are 'read' rather than given by an intrinsic meaning that exists separate from the act of interpretation. He argues that interpretation is framed by "interpretive communities" which are "made up of those who share interpretive strategies ... for constituting the properties" of a text. With rival "interpretive communities" there may be no settled meaning of a concept or set of concepts that constitute theories of social action and belief.
} 
not least of which is the realisation that 'solutions' may be partial and partisan-statute may be a constraint on innovation as rules and regulations designed to solve past problems stifle attempts to meet the future (Roe 2006). The challenge is to bring together the common interests of the various stakeholders in investment management so as to re-conceptualise the practice of investment in ways that are genuinely innovative. This may seem to be a form of idealism by the back-door. What is remarkable, however, is the variety of strategies being developed to do just that by the various interests and parties embedded in the industry. In conclusion, I remind the reader that UK governments over the past thirty years have repeatedly confronted the question of the social value of investment only to duck the issue. If recent industry initiatives can be coordinated about the frontiers of investment practice, then government may be willing to substantiate our common interests in long-term sustainable investment (Woods and Urwin 2010).

\section{Common law and statute}

If the common law is seen as an 'institution', it is based upon the accretion of private rules as regards the governance of exchange relations given form by the legal apparatus. When discussed, more often than not, reference is made to contract, tort, equity and trust law. For many, the common law and its adjudication developed in accordance with the changing structure of economic relations, being a reflection of the needs of private agents to give formal expression to their relationships (Epstein 1995). As such, at one level, the common law can be understood in terms of its functions; that is, its conception and development can be seen in utilitarian terms. If form necessarily follows function, it has been suggested that slow rates of adaptation in the common law have often constrained economic development such that whole societies can be differentiated one from another in terms of their willingness or capacity to adapt inherited rules of conduct in accordance with the changing needs of private agents. The common law is not, axiomatically, an efficient institution (Trebilcock 1993).

This is, of course, a rather simple conception of the origin and development of law as an institution. Nonetheless, it does capture the long sweep of history and the ways in which inherited rules of conduct have changed in response to, and facilitated the pace of, economic and social development (Hawley and Williams 2001). Even so, there remain crucial questions to be answered. First, what types of rules qualify for inclusion in the common law? Second, are some rules more important than others? The first question is easily answered. In The Concept of Law, HLA Hart (1961) argued that the common law is nothing more or less than accepted norms and conventions given institutional form. That is, the common law is a set of widely-accepted standards of customary practice 
conceived and given expression by the actions of private agents. As such, their legitimacy derives from society rather than the state, at least in the first instance. In the second instance, legal institutions provide authoritative interpretations of widely accepted standards of customary practice and provide, where needed, mechanisms for determining and enforcing restitution.

Some rules are clearly more important than others. Relative importance can be determined, in part, by reference to the generality of accepted norms and conventions and the degree to which they are supported by society at large. Here, though, those that hold to a utilitarian conception of the common law argue that those rules that add most to social welfare are clearly to be preferred over the rules that have less effect on social welfare. For others, disputing the utilitarian conception of law, accepted norms and conventions typically embody moral commitments and hence claim superior status when counting-up the net benefits of one rule over another. For example, whereas contract is an expression of an accepted norm (making a commitment) and a convention (a means by which commitments are recognised) some theorists believe that the value of contract is to be found in its contribution to economic welfare, whereas others suggest that contract is based upon an important moral principle (honouring promise-making; see Fried 1981). ${ }^{3}$

In effect, the most important principles of common law are expressed as rules of behaviour. Their significance is to be found in their generality and widespread acceptance whether legitimated on utilitarian and/or moral grounds. Inevitably, principles are permissive without elaborating their applicability for each and every possible case and seek to pre-empt actions and behaviour that would, in some way or another, violate accepted norms and conventions. This suggests that the common law tends to lag behind changes in norms and conventions, being backwards looking rather than leading forward (Woods 2011). This also implies that the common law is not so much coercive as it is authoritative. That is, enforcement costs are low because the common law codifies accepted practice subject to the need for authoritative interpretations of its principles in instances that are unusual or different from past experience. The weight of exceptions or so-called 'hard cases' trigger the systematic reconsideration of the meaning and applicability of principle (Dworkin 1978).

By contrast, statutes begin life as formal legal instruments representing the goals and objectives of the sponsoring state. As such, they are part of the legal framework and institutional structure that

\footnotetext{
3 . Norms and conventions are closely related. Here, I assume norms carry moral values in that conformity implies social virtue (just as violating norms implies disapproval) (Pettit 2002, 314-15). Conventions promote coordination amongst private agents and are derived from precedent tested against new circumstances and the extent to which common interests may encourage the search for convention (Lewis 1969, Ch. 1).
} 
define the powers of government as well as the obligations and responsibilities of residents to the nation-state. More often than not, statutes are conceived with respect to realising certain identified objectives in specific domains of social, political, and economic life. For some theorists, of course, statutes are best understood as frameworks for public and private behaviour, setting the boundaries of what is permissible and impermissible with appropriate incentives and sanctions dependent upon the benefits and costs of regulation. As frameworks for action, statutes can have wide scope and significance. Alternatively, statutes may be rather narrow conceived to solve a problem or class of problems that are deemed significant for the state and/or its constituents. As solutions to problems, statutes typically require elaborate rules and regulations administered by agencies with appropriate coercive powers and responsibilities.

At one level, statutes as frameworks draw their inspiration and legitimacy from accepted norms and conventions. Statutes as frameworks may also elaborate inherited common law traditions in ways deemed consistent with the changing nature of economy and society. If justified by accepted norms and customs, statutes tend to look forward rather than backwards linking together the past, present, and future. So, for example, legislation may establish by statute institutions like carbon markets hitherto not available to private agents, thereby providing an accepted framework for the pricing of economic activity consistent with public commitment to long-term sustainability. Market pricing as opposed to direct state control of carbon emissions embodies a series of (contested) assumptions about the proper role of government in relation to individual volition and responsibility (Knight 2010). As solutions to problems, statutes may be only tangentially related to principle; their social acceptability may simply derive from their efficacy.

Idealist conceptions of statutes as frameworks tend to suggest that, when considered as a whole, these instruments give societies their institutional shape. As such, they may provide societies a blueprint for common commitments and cooperation. Furthermore, idealist conceptions suppose that shared values ensure that statutes as frameworks cohere with one another such that the legitimacy of the whole is found, in part, in the ways in which they provide a comprehensive blueprint for the future. However, realist conceptions of the nature and scope of statutes dispute the notion that there are, in fact, shared values that underpin the institutional edifice of societies. Furthermore, realists have a critical view of the relationship between state and society suggesting, more often than not, that organised interests may conspire to capture certain elements or institutions of the state for their own purposes (Roe 2006). By this account, invoking principle to 
justify a statute is best understood as a rhetorical move aimed at claiming legitimacy rather than an objective reality (Runciman 2008).

Two important implications follow from realist conceptions of statute. One is that statute is, more often than not, a solution to a problem rather than a coherent framework for social action. The scope and significance of such statute depends upon the degree to which those that stand to benefit from statute are able to organise a broad coalition of support (in the face of those that would lose from such a statute). The broader the coalition of supporters, the more complex the relevant legislation and the less coherent the link is between ends and means. A second implication also deserves emphasis. Once established, statutes are difficult to dislodge. It is easier to write new statutes around newly formed coalitions even if this means creating agencies and institutions that are effectively competitors to those already established. So, instead of statutes forming a blueprint for common commitments and cooperation, when looked at as a whole they may be a complex patchwork quilt of sectional interests that is less than the sum of its parts. ${ }^{4}$

\section{Re-reading Harvard College v. Amory}

The classic case defining fiduciary duty relevant to investment management comes from a case decided in 1830 in Boston, Massachusetts. In Harvard College v. Amory 26 Mass. (9 Pick.) 446 (1830), the College and Massachusetts General Hospital (MGH) sued a trustee seeking restitution of losses sustained in an investment fund established by a wealthy businessman for his surviving widow. In his will, the businessman had provided capital for investment on behalf of his widow and, upon her death, the disbursement of the assets of that fund to the two institutions. The two trustees identified by the businessman as executors of his will and trustees of the fund were provided "the sum of $\$ 50,000$ in trust nevertheless to loan the same upon ample and sufficient security, or to invest the same in safe and productive stock, either in the public funds, bank shares or other stock, according to their best judgement and discretion, hereby in joining on them particular care and attention in the choice of funds, and in the punctual collection of the dividends, interest and profits thereof, and authorising them to sell out, reinvest and change said loans and stocks from time to time, as the safety and interest of said trust fund may in their judgement require."

\footnotetext{
4. Consider, for example, the comment made by Sir Keith Joseph (UK Secretary of State for Social Services) when introducing the Conservative government's Social Security Bill (November $28^{\text {th }}, 1972$ ). On the shape of the social security system, it "resembles some rambling Gothic pile to which enthusiasts have added a range of well-intentioned improvements in a whole variety of styles. It is generally agreed that the system needs urgent reconstruction" (Hansard 847:243-77). The social security system was to suffer further "improvements" at the hands of successive governments until 1995 and then again in 2005.
} 
The businessman's will and the intentions of the executors and trustees (as one) to invest according to the mandate (above) were not contested by either institution in the court of probate. Having invested in the stock of manufacturing companies, matching previous investment decisions of the deceased, the trust incurred losses on those investments, such that when the surviving trustee came to retire the two institutions sought restitution of those losses from the trustee. As the Massachusetts Supreme Court rehearsed the facts of the case, assessed the responsibilities of trustees, and the virtues of different types of investments, reference was made throughout to English common law. In that regard, Justice Putnam (p. 22) observed

(A)II that can be required of a trustee to invest, is, that he shall conduct himself faithfully and exercise sound discretion. He is to observe how men of prudence, discretion and intelligence manage their own affairs, not in regard to speculation, but in regard to the permanent disposition of the funds, considering the probable income, as well as the probable safety of the capital to be invested.

Friedman $(1964,554)$ noted that this definition of prudent behaviour "has been so often quoted, cited, and repeated, that the eye is apt to pass over it without noticing the precision of its phrasing." Friedman explained its conceptualisation by reference to Boston society of the time, including its strong family commitments, the rise of a mercantile aristocracy, and the common use of trustee institutions to manage investments. So, "men of prudence" was not some abstract, dislocated reference point but local people, including businessmen. Equally important, and resonating with late 20th century investment strategy and the management of risk and returns, the court emphasised that investment is all about probabilities (risk) rather than certainties. ${ }^{5}$

The court also noted that the testator was a "man of extraordinary forecast and discretion" and that his wealth was not an accident, but the result of "calculation and reflection." Equally, the court made considerable play of the fact that the executors and trustees were, in fact, family members, being (respectively) the brother and cousin of his wife (the surviving widow). There was no reason to doubt the competence of the testator, there was no reason to doubt the motives of the trustees, nor was there reason to doubt their judgement given the norms and conventions governing the behaviour of similarly-located individuals. Considering the investment strategy conceived by the trustees, the court argued that the investments made were consistent with local experience and

\footnotetext{
$5 \%$ Noted in the court's judgement was a distinction between investment as a systematic process of risk management and playing the market as one might gamble in lotteries. Hacking (1990) provides an historical account of changing 18th and 19th century perceptions as regards the nature of chance and the increasing importance of probability as a formal mechanism for taming chance.
} 
were not like lotteries and games of chance. There were reasonable grounds to invest in manufacturing companies considering the risks associated with options such as public funds. ${ }^{6}$

At one level, this decision is rightly lauded for its scope and significance for common law jurisdictions around the world. At another level, it should be noted, as many commentators have noted, that it was not determinate of US standard practice; Hawley et al. (2011) observe that nearly 40 years later the court returned to the more constrained English standard, including a general prohibition against investments in traded company stocks and securities. This held for the majority of states through to at least the 1930s; state lists of permitted investment instruments were only abandoned in the 1940s after their costs became widely acknowledged. It took publication of the American Law Institute's (1992) Restatement (Third) of Trusts, which included reference to the use of modern portfolio theory, for US standards of fiduciary duty to return to the expansive conception of trustee responsibility enunciated in Harvard College v. Amory (conceptualised as the prudent investor rule; see also Langbein and Posner 1976).

If surprising when considered in the light of the development of the financial services industry over the second half of the 20th century, more surprising was the comment made by Aalberts and Poon $(1996,39)$ to the effect that it was possible to distinguish between private trusts and estates and pension funds. Noting fiduciaries of pension funds are subject to the prudent man rule, they also suggested that pension fiduciaries are different because they "do not have to contend with the conflict between income beneficiaries and remaindermen, but benefit from a constant influx of contributions, and realize favourable tax treatment." This comment implies considerable ignorance of the realities of defined benefit pension plans. In any event, through the passage of the Employee Retirement Income Security Act (ERISA) of 1974, the federal government determined that "a fiduciary shall discharge his duties ... With the care, skill, prudence, and diligence under the circumstances, then prevailing that a prudent man acting in a like capacity and familiar with such matters would use in the conduct of an enterprise of a like character and with like aims".7

\footnotetext{
\%. Coming to the issue of investment, risk, and judgement more than a century after the South Seas bubble of 1720 , it was obviously important for the court to distinguish between the sober judgement of members of the Boston community and the apparently unfettered mania of speculators caught up in the rumours and misinformation of London coffee houses, the press, and Exchange Alley. Dale (2004) provides an account of the bubble, drawing connections with the irrational exuberance of the TMT bubble (see also Shiller 2000).
}

7/. Pub.L. 93-406, 88 Stat. 829 (Sept. 2, 1974). 
The relevant community of practice was not Boston or a state jurisdiction but rather a similarly placed individual with the same set of goals and objectives and consequent responsibilities (see also Schanzenbach and Sitkoff 2007). The geographical extent of this community of practice was, effectively, the United States (and the jurisdiction of federal district courts). Note, however, in ERISA the expansive definition of fiduciary duty was conditional on the "exclusive purpose" of a pension fund fiduciary, "reasonable expenses", the diversification of plan investments "so as to minimise the risk of large losses", limits on the ownership of overseas assets, and the representation of other parties' interests "adverse to the interests of the plan or the interests of its participants or beneficiaries". These conditions made explicit expectations of the court in Harvard College, which, according to Friedman (1964), were apparent in the conservative culture of Boston in the early 19th century. Passage of ERISA was premised upon the belief that the (state-by-state) community of practice was not robust enough to impose discipline upon those who would violate beneficiaries' interests.

In fact, the circumstances of Donovan v. Mazzola 716 F2d 1226 (1983) suggest that community norms and conventions may undercut fiduciary duty when trustees join together in ways that advance the interests of third parties to the detriment of beneficiaries. ${ }^{8}$ In this case, representative of a series of related cases that hinged on fiduciaries' conflicts of interest, 'community' norms and customs were the object of judicial scrutiny. ${ }^{9}$ Trustees of a union-sponsored pension plan made unsecured loans from the fund to another entity sponsored by the union, employed a person known to trustees to conduct a feasibility study who was unqualified to do so, made loans to another entity involving that person, and granted moratoriums on loans made to the first entity. Referencing common-law expectations, the federal appeals court upheld the decision of the district court barring the trustees from acting as fiduciaries on any other fund, removing them from the current fund,

8. This case along with Donovan v Bierwirth 538 F.Supp. 463 (E.D.N.Y. 1981) have been widely cited in the relevant case law, case commentaries, and amongst academics. See, for example, Rosenburgh and Spieler (2009) and, more generally, Stone (1994).

$\%$ Wider issues are suggested by this case, notably how courts and regulators should deal with trustees who have various other interests that may, in fact, benefit beneficiaries. Langbein (2007) notes that the modern world of financial management and investment is complex, multifaceted, and bound by overlapping interests. It is difficult to sustain the argument that trustees acting in the 'sole' interest or 'exclusive' interest of beneficiaries would necessarily benefit beneficiaries when skilled trustees may be well-placed to take advantage of market information due to other responsibilities thereby enabling investors to share good fortune. See Thornton (2008) on changes to the UK Trustee Act (2000) that capture aspects of the complex relationships and overlapping interests that characterise the investment value-chain. Note, in the US, there have been attempts to extend the reach of who counts as a fiduciary for this reason. See Berry (2011) arguing for the same cause in the UK case. 
rescinding transactions between the fund and those entities, and requiring trustees to reimburse the pension fund for "any present or future losses stemming from violations" of their fiduciary duties.

\section{Re-reading Cowan v. Scargill}

Decided in April 1984, Cowan v. Scargill Ch. 270 [1985] was precipitated by the newly elected president of the National Union of Mineworkers (NUM) joining the trustee board of the Mineworkers Pension Scheme in 1982. At the time, there is widespread debate about the causes and consequences of the UK's economic performance over the previous decade (Peston 1980). ${ }^{10}$ Further, with a Conservative Prime Minister committed to radically altering the balance between labour unions and management and promoting denationalisation and deregulation in industry and the financial sector, this case can be read as one step towards open hostilities between the union and national government. It is normally read as the definitive judicial decision effectively outlawing the consideration of "moral and social matters" in pension fund investment decision-making (Freshfields Bruckhaus Deringer 2007). It is the standard UK (and British Commonwealth) reference point when considering socially responsible investment, including response to climate change (see Thorton 2008 on related cases).

Joining the trustee board of the fund as the newly elected president of the Mineworkers union, Scargill brought to the table an agreed policy of the NUM conference that the fund not invest in oil stocks (deemed a competing industry with coal), and that the fund withdraw from overseas investments. This policy was clarified by the plaintiffs to be a claim on the fund's Investment Strategy and Business Plan 1982 to the effect that "(1) there is to be no increase in the percentage of overseas investment; and (2) overseas investment already made is to be withdrawn at the most opportune time; and (3) the committee adopts a proposal within the business plan of not investing in energies which are in direct competition with coal." Justifying this policy, Scargill repeatedly argued it would be in the best interests of beneficiaries and he contended that the union had obtained a legal opinion to the effect that this policy would be consistent with fiduciary duty.

\footnotetext{
${ }^{10} \%$. The Callaghan government initiated an enquiry into recent poor UK economic performance, focusing upon the functions and performance of financial institutions, including pension funds (HM Government 1980). For some commentators, poor economic performance was due to banks failing to lend to private enterprise. For others, including the recently elected Conservative government, the problem was far-reaching having to do with the failure to control government spending and provide long-term incentives to borrow (Capie 2011, Ch. 13). Led by the previous Labour Prime Minister, Harold Wilson, the inquiry considered directly regulating pension funds to invest in UK enterprise (a policy position put forward by the Trades Union Council). The Wilson report ultimately rejected this idea, but noted the significance of pension funds in the national and international context.
} 
Megarry discounted the first claim by clarifying the nature of pension funds and dismissed the second noting "Mr Scargill's assertions of such support are simply untrue".

Observing that retired miners, their widows and children were dependent upon the pension fund for their well-being, Judge Megarry suggested that any distinction between the majority of beneficiaries and the beneficiaries of private trusts could not be sustained. Drawing upon two US federal court decisions concerning the responsibilities of pension fund trustees, the judge concluded that whatever the structure and organisation of the pension institution, these decisions had "reaffirmed the duty of undivided loyalty to the beneficiaries the trustee owes" based on a commitment to "the best interests of the beneficiaries." Arguing that these cases were "soundly based on equitable principles, which are common to England", he concluded that "pension funds are in general governed by the ordinary law of trusts". Referencing 19th century English common law, Megarry stated "the standard required of a trustee in exercising his powers investment is that he must 'take such care as an ordinary prudent man would if he were minded to make an investment for the benefit of other people for whom he felt morally bound to provide'".

Importantly, Megarry did not discount the notion that there may be "a strong case" for legislation regulating pension fund investment overseas and at home, but this was the responsibility of government, not trustees. Further, in relation to investment in South Africa, the judge noted that, while trustees are barred from making investment decisions based upon "social or political reasons", they could reasonably consider issues related to the "political stability in South Africa and the longterm financial soundness of its economy." Just as importantly, Megarry recognised that there may be some issues of such significance for the overwhelming majority of beneficiaries that it is reasonable to suppose that the relevant fund could "receive less by reason of the exclusion of some of the possibly more profitable forms of investment." He also said, however, "the present case is not one of this rare type of cases." See Berry (2011) and Richardson (2011) for related commentary.

Closer reading of the case would have it that it was less about proper investment policy and more about the governance of the fund. Scargill sought to overturn the structure and management of the pension fund in the interests of his union's political objectives. Using the $5+5$ membership of the board (five employer and five union representatives), and the fact that it was based on consensus without the prospect of a casting vote, Scargill sought to hold the board hostage to the union's policy. Disputing the division of responsibilities between the board and the Joint Investment Subcommittee, wherein the latter composed of investment experts and fund investment staff 
managed the investment process and the former ratified the fund's overarching Investment Strategy, Scargill sought to impose NUM policy. Disputing the minutes of meetings, arguing they did not reflect decisions taken, Scargill sought to dominate the fund's decision-making process. Disputing the interpretation of fiduciary duty, Scargill invoked a legal opinion justifying his stance while refusing to provide the opinion to the board. Scargill also claimed pension funds were different from private trusts and, as such, commonly-accepted norms and conventions did not apply.

Setting aside Scargill's attempt to control the fund, the court returned to the common law and to American precedent classifying beneficiaries in a manner consistent with the common law while invoking US federal court decisions relevant to the issues of substance considered in this case. In this respect, the 'community of practice' invoked to sustain Megarry's opinion was found in legal formalism rather than similarly-positioned fiduciaries bound together by shared norms and conventions with regard to investment practice. Vital for his opinion was the desirability of risk management through stock diversification established in the UK Trustee Investments Act of $1961 .{ }^{11}$ Equally important, however, was the sense in which the responsibility of trustees was conceived in terms of the individual trustee or prudent man as opposed to men (or a group of like-minded people with common responsibilities) without reference to what they might do on their own account. Subtly, Megarry's opinion discounted community norms and conventions precisely because of the union's attempt to define, in political terms, the meaning of customary practice.

In effect, the 'community of practice' so important in conceptualising fiduciary duty in the Harvard v Amory case was replaced in Cowan $v$ Scargill by invoking statute and an authoritative legal interpretation of pension fund trustees' separate responsibilities. Equally, the decision in this case legitimated the governance and management of large pension funds where responsibilities are allocated on the basis of expertise and professional judgement. Given the political agenda, the court decided that trustees, in this case at least, could not be relied upon to honour their moral commitment to the welfare of beneficiaries.

Just as the Cowan case turned on the attempt by a union to dominate the investment policy of a pension fund, with the death of Robert Maxwell in 1991 it became clear that he had "ran his companies and pension funds as if they were one. He moved assets between them as best suited his overall interests" (HM Government 2001, ix). It appears that the pension schemes' trustees deferred to his claim over the management of the companies' pension assets. Maxwell controlled the

\footnotetext{
11/. Trustee Investments Act 1961 (c. 62).
} 
reporting of company and pension fund investments, oftentimes delaying reporting, minimising reporting, and ensuring that reconciliation of positions between accounts was not possible. Whether trustees were aware of Maxwell's tactics remains unclear. Trustees acknowledged, however, Maxwell's "strong personality", "his own management style", and a shared belief that Maxwell had sustained high rates of return for the pension funds (HM Government 2001, 74). The prospect of a $£ 450$ million shortfall in the companies’ pension schemes prompted the government to initiate a review of the legal status and regulation of pension schemes. The Goode Report (1993) was the basis for legislation to redress the situation including the establishment of the Occupational Pensions Regulatory Authority in 1995.

\section{Trust law and statute}

Re-reading important cases from the past while making connections, backwards and forwards, between jurisdictions with regard to developments in English common law allows us to see aspects otherwise submerged in standard interpretations of these cases. Stripping cases of their detail is, of course, the way legal positivists produce rules for behaviour that apply across relevant cases rather than simply to specific cases (Coleman 2001, 77). So, it is not surprising that the details of these cases have been submerged so as to leave general rules about trustee obligation and fiduciary duty. In this section I emphasise neglected aspects of these cases which, from our perspective located in early 21 st century financial capitalism, deserve closer attention. From these neglected elements, we can discern the clues that unlock the puzzle as to why fiduciary duty has been marginalised and why fund governance has assumed such significance in the contemporary world.

Take, for example, the issue of trustee commitment; alliances and relationships that extend beyond their obligations with respect to beneficiaries' well-being. In Harvard College this issue was resolved in two ways that reinforced one-another. On the trustee side of the equation, they were deemed to have a strong moral commitment to the welfare of the testator's beneficiary by virtue of their familial relationship with the beneficiary. As well, third parties to that relationship were kept at arm's length; their interests were treated as "residual" and excluded from consideration in the investment process until the interests of the beneficiary were exhausted. By contrast, trustees in Donovan and in Cowan had a rather remote relationship to the vast majority of beneficiaries. In both cases, trustees may have had familial relationships with some beneficiaries: but it seems likely that any such relationships were swamped by other kinds of relationships based upon the notional interests of the unions or organisations to which they belonged. In other words, the rule of fiduciary duty was required to stand in place of moral or emotional commitment to beneficiaries' interests. 
In the Harvard College case, the interests of third parties to the primary relationship were kept at bay by virtue of being designated "residual" claimants. By contrast, in Donovan trustees were inveigled to frame and implement investment strategy so as to sustain third-party interests. In Cowan, the union's political interests were claimed to have equal standing with beneficiaries' interests in the sense that the latter would be served by the former. As for Robert Maxwell, his companies' interests were served by suborning the Mirror Group's pension schemes' assets. Whereas trustees were responsible in each instance for realising beneficiaries' welfare, one way or another they were willing to treat those interests as fungible in relation to other claims on their decision-making. At one level, it is entirely plausible that investment strategy can be framed in ways that meet subsidiary objectives (as suggested by Megarry when referring to the long-term risks of investing in South Africa). Nonetheless, fiduciary duty requires an explicit ordering of goals and objectives such that the first priority dominates any other goals and objectives.

An intriguing aspect of Harvard College concerned the recipe for fiduciary duty provided by community norms and conventions. By virtue of the particular culture of Boston in the early 19th century, these norms and conventions were apparently easily codified in common law. By contrast, it would seem that the idealised 'community of practice', which sustains fiduciary duty, is all too easily subsumed by 'local' commitments and relationships. In judgement, the courts on both sides of the Atlantic reached for statute to set the record straight: in Donovan, the federal appeals court referred to ERISA (1974) whereas in Cowan the court referred to the UK statute (1961) on the diversification of risk in investment management. Either statute was invoked as an expression of community norms and conventions or statute was invoked because the substantive issues involved in pension fund investment are more complex than private trusts or because it was not possible to identify relevant and accepted norms and conventions. One way or another, it would seem that modern society cannot deliver on the promise of the common law. As such, given the power relations involved in Donovan and Cowan, statute was invoked to legitimate judicial authority.

In Harvard College, the two trustees were apparently joined in a common mission to realise the testator's wishes. By virtue of their intimate relationship to the beneficiary as well as their social standing in the community, it seems that common agreement was easily realised. But notice, in Cowan any sense of a common mission was disturbed by the union's interests prompting Megarry to explicitly locate fiduciary duty with the individual rather than the group or collective. His reading of fiduciary duty isolates the individual from the community precisely because the community may 
make competing demands on his or her loyalties. Two implications follow. First, by his account in acting together trustees should begin from their own legal responsibilities and must join together to set commonly agreed objectives. Second, realising those objectives is a matter of negotiating agreement in circumstances where it may be difficult to be precise about what constitutes beneficiaries' interests separate from those of the sponsors.

Even well-intentioned trustees may be uncertain about their legal responsibilities if, as the common law would suppose, the appropriate reference point is the community of practice. Where there are competing interpretations of community norms and conventions, uncertainty about their legal responsibilities may make negotiating agreement with other trustees problematic. It is not surprising individual trustees gravitate to what appear to be, if only momentarily, authoritative interpretations of both their responsibilities and the proper way forward for trustees as a collective. At the same time, recognising the possibility of contravening norms and conventions, trustees uncertain about their legal responsibilities and the interests of others may gravitate to recipes for decision-making that have the virtue of judicial respectability. Instead of looking forward and being part of a process whereby community norms and conventions adapt to a changing environment, trustees may seek refuge in the past where certainty prevails, albeit at the cost of reinforcing convention (contra expectations regarding the potential of the common law; see Calabresi 1982).

In this light, the Goode Report (1993) on the law and regulation of UK pension schemes can be read as the first instalment in a legislative programme designed to articulate and clarify the responsibilities of trustees. It did so linking trustees' "rights and duties" with statutory requirements and to the rules and regulations of the newly established regulator. Included in these provisions was the right of scheme members to make appointments to the trustee board, thereby introducing directly into trustee deliberation the interests of beneficiaries through the process of appointment and representation. At the same time, the legislation sought to protect pension scheme members' accrued rights via a funding regime that would remove discretion from scheme sponsors and trustees according to the terms of a minimum solvency requirement. Passed in 1995, the Pensions Bill was a solution to a problem and was conceived by government as a comprehensive framework for pension administration, funding, and regulation.

\section{Statute, governance and fiduciary duty}

Following passage of the comprehensive statutory framework regulating UK pension funds, the Labour government welcomed the Myners Report (2001) on investment management. Initiated by 
the Chancellor, Myners was charged with the responsibility of identifying the barriers to innovation in pension fund investment (compared to US funds). Focusing upon the constitution and governance of UK pension funds, Myners concluded that the typical pension fund trustee lacked the necessary skills and resources to be an effective investment decision-maker. Further, he concluded that UK pension funds were far too conventional in terms of their investment strategies, congregating around accepted benchmarks of performance rather than focusing upon asset allocation decisions consistent with funds' liabilities. Myners was especially critical of the benchmarking phenomenon, implying that it was a rather naïve conception of investment management considering the risks associated with effectively unmanaged liabilities. These arguments gathered force in part by virtue of the 2001 implosion of the TMT financial bubble in the aftermath of 9/11 (see also Shiller 2002).

Assuming trustees act on behalf of beneficiaries, Myners doubted whether they had the appropriate levels of "prudence, discretion and intelligence" given the risks and uncertainties associated with investment management (quoting and paraphrasing Harvard College). Myners also sought to shift the reference 'community of practice' from UK trustees to best practice found in a number of large US pension funds, industry experts, and the frontiers of investment management. He suggested that UK norms and conventions reinforced complacency while adding unjustified costs to the investment management process. Furthermore, in relation to the responsibilities that go with the control of large pools of financial assets in the modern economy, Myners contended that trustees had failed to sustain their commitment to shareholder value. He argued that corporate engagement should be seen as an element in an expanded conception of trustee fiduciary duty (formally recognised in 2010 by the UK Financial Reporting Council's voluntary Stewardship Code).

If debate about the Myners Report ignored private equity, his critique of trustees' qualifications prompted government legislation in 2004 designed to promote trustee knowledge and understanding and set codes of practice relevant to the governance of pension institutions. Establishing The Pensions Regulator (TPR), the Labour government joined expectations about improving trustee knowledge and understanding with statutory recognition of beneficiary representation on trustee boards. Furthermore, by promulgating codes of practice aimed at promoting best practice pension fund governance, the government through TPR used the mantra of 'comply or explain' to encourage funds to be more systematic about 'managing' the governance 
of their procedures and decision-making processes. ${ }^{12}$ At the same time, the government resisted the temptation to rewrite the definition of fiduciary duty in a manner consistent with the relevant US standard as detailed in ERISA Section 404 (1974), which refers to "a prudent man acting in a like capacity and familiar with such matters" in "an enterprise of a like character and with like aims".

The first codes introduced in April 2005 referred to the duties of sponsors, fund executives, and trustees as regards notifying the Regulator of breaches in the law and a related duty to provide timely notification to the regulator of possible problems associated with pension funding that could result in a call upon the Pension Protection Fund (PPF). Arguably, codes three, five, six, and twelve also referred to the funding of defined benefit and defined contribution schemes. By contrast, codes four, ten and eleven are more related to the rights of pension plan participants and the obligations on schemes to respect those rights. By contrast, codes seven, eight and nine refer to trustee knowledge and understanding, the provisions appropriate for the appointment of membernominated trustees, and the necessary internal controls for ensuring the proper management of pension schemes. Overall, the codes of practice were designed to ensure the accountability of trustees, plan sponsors, and fund executives to the Regulator, articulating the duties consistent with what would be defined as fiduciary duty.

At one level, the Regulator has used codes of practice to substantiate the interpretation and effective implementation of fiduciary duty as the principle underpinning the governance of pension funds. It has done so because the norms and conventions associated with the 'community of practice' have been shown to be either ineffective given the responsibilities and significance of UK pension plans for retirement income or, worse, subject to dispute. Further, responding to past cases where trustees were effectively 'captured' by other interests, the appointment of membernominated trustees to represent beneficiaries introduced the possibility of governance and decisionmaking being systematically undermined by gross differences in trustee competence and skills. Anticipating the possibility that the average trustee would not be able to give effect to fiduciary duties, codes of practice have been introduced to compensate for this possibility. As suggested elsewhere, there is a significant tension between representation and expertise (Clark 2007).

\footnotetext{
${ }^{12} /$. It is remarkable that regulation through 'comply or explain' has been so effective; after all, there remains a significant degree of fund-specific discretion in whether or not to abide by TPR's codes of practice. Unlike the US, this type of regulation is not accompanied by formal rules and regulations setting out sanctions on those that fail to comply. In part, this may be thought to reflect the preference of UK government for 'principles' rather than enumerated regulations. It may also reflect the weakness of UK government in the face of the significance of the financial sector to the UK economy.
} 
Importantly, the codes of practice are related to the Regulator's statutory responsibility to oversee the funding of defined benefit pensions and in particular the obligations on sponsors to make good on pension promises. Notice, however, the Regulator is, in effect, a mediator between trustees and sponsors; as the Regulator has a responsibility to sustain pension funding in relation to the PPF, it does so in a way that seeks to dampen trustee demands on sponsors that would otherwise precipitate a claim on the PPF's assets and benefit guarantees. So, for example, through the recent global financial crisis the Regulator encouraged trustees to develop extended 'recovery plans' so as to provide for scheme funding based, in part, upon assessment of the notional 'long-term' financial strength of the sponsor. In this respect, negotiations between trustees and scheme sponsors have typically involved agreeing on investment strategies and expected rates of return targets. In this sense, fiduciary duty is contingent upon the particular circumstances of sponsors and negotiation with the sponsor about its capacity to incrementally fund current and expected shortfalls.

Whereas fiduciary duty is commonly understood to govern the relationship between trustees and beneficiaries, the effect of statute has been to introduce into that relationship two other parties: the government through TPR and the PPF and the employer as scheme sponsor. If the regulator represents the public interest in workplace pensions, it also represents the government interest in limiting calls upon the PPF. At the same time, given the challenging market conditions facing many private pension schemes sponsors, trustees' claims on scheme sponsors have been deemed by the Regulator to be conditional rather than absolute. In effect, the Regulator is risk averse in a political sense but may impose on trustees a level of risk-taking that is antithetical to the best interests of beneficiaries in the full-funding of their pension schemes.

\section{Innovation and investment}

Advocates of fiduciary duty believe that it provides an adaptive, non-governmental mechanism for innovation in investment management. Based upon independent, expert judgement in the context of 'communities of practice' capable of vetting new ideas against collective experience, the common law would seem to have many of the attributes Surowiecki (2004) suggested is characteristic of the "wisdom of crowds". As such, it need not share with government bureaucracies the inertia typical of centralised, administrative institutions that rely upon rules and regulations to affect private behaviour. By contrast, it is supposed that the doctrine of fiduciary duty codifies practice disciplined by shared norms and conventions in ways that promote the evolution of private behaviour consistent with social welfare. For La Porta et al. (1998) it is the bedrock of financial innovation and development, distinguishing the histories of Anglo-American economies from the various 
continental European traditions. Reliance upon fiduciary duty is one reason why Anglo-American countries tend not to use administrative rules for asset allocation (as illustrated by OECD 2011a).

However, at every turn, governments have used statute to buttress the authority of fiduciary duty (establishing authorities to substantiate the interpretation of the principle through rules and regulations). In effect, governments have filled in the gaps left by contestation over community practice so as to realise promised pension benefits and their security. For example, the US federal government has used ERISA to clarify and define the standards of expertise and experience deemed consistent with fiduciary duty. In this respect, statute has emphasised expertise over commonsense denying the 'wisdom of crowds'. In the UK, government has sought to affect the application of expertise through promulgating 'comply or explain' codes of practice thereby attempting to balance the need for competence with a commitment to representation. In the UK, the government has also sought to affect standards of trustee knowledge and understanding as well as the principles and procedures of fund governance so as to sustain effective investment management.

In a similar manner, governments have used legislation to establish the significance of investment principles including portfolio diversification and, at the limit, modern portfolio theory (MPT). It is apparent that, if left to the common law, MPT would have remained at the margins of community norms and customs in many jurisdictions. This has a number of lessons for those advocating a turn to the principles of long-term investment, including responsible investment and sustainable investment. In the first instance, it is apparent that advocates of MPT struggled for recognition in the face of the inertia associated with community norms and conventions. In the second instance, its advocates waged a long-running campaign for recognition based upon a combination of theoretical insight and innovation and the formulation of practical recipes for investment management. In the third instance, its advocates were successful because they effectively commandeered public and private institutions of standard-setting.

It seems inevitable that governments will not lead the process of articulating and substantiating the principles of long-term investment. Similarly, it seems inevitable that governments will be enlisted to formalise the principles of long-term investment in rules and regulations consistent with authoritative interpretations of fiduciary duty. But it also seems inevitable that academics and the investment community will need to take responsibility for substantiating the theory of long-term investment and formulating practical recipes for investment management. This project is, no doubt, very ambitious. Even so, in the aftermath of the global financial crisis and widespread 
disenchantment with the principles and practices of what Merton and Bodie (2005) referred to as the 'neoclassical' theory of financial markets, there is a ready-made audience in government for conceptual innovation. As such, there appear to be a number of strategies being used to 'organise' the process of conceptual innovation relevant to long-term investment. These are noted below, paying regard to the diversity of strategies as well as their various sponsors.

Best practice case studies: often sponsored by leading consulting companies, and based on collaboration with experts inside and outside of the industry, these projects tend to focus on pension fund governance (see Clark and Urwin 2008). Here, the goal has been to set the agenda with respect to informal or formal codes of practice (in effect, anticipating government policy and regulation). Considering that government typically does not have the resources to undertake the detailed research necessary to identify best practice, and considering that trustees themselves are less knowledgeable about the nature and scope of pension fund governance around the world, these projects have been effective in strengthening the resources available for investment decisionmaking. In large part, these studies take as given conventional definitions of fiduciary duty and the statutory obligations of trustees but articulate new ways of conceptualising the investment management process.

Clubs of research and practice: sponsored by a diverse range of institutions, bringing together relatively small groups of investors around a particular issue or theme, these clubs seek to translate research in the practice of investment management. A particularly successful instance was the recent Mercer report on climate change and long-term investment. There, like-minded investment institutions underwrote the costs of research on the probable nature and scope of climate change through to 2050 and its implications for investment management. Rather than framing the problem as an ESG (environment, social and governance) issue, it was framed as an issue of investment value over a series of time horizons going forward through to 2050. A similar type of study, this time aimed at establishing investment protocols, has been initiated by Towers Watson through their thought leadership group.

Multilateral and international standard setters: whether sponsored by the accounting professions or by other independent, professional bodies, standard-setting has become a crowded field of endeavour. Based upon research and their own communities of practice, these institutions have sought to establish principles and practices relevant to even the most difficult issues and thereby stimulate forward-looking decision-making. Importantly, in this world standard-setting is a 
collaborative project amongst private agents sometimes (but not always) given status by government and international organisations. If epitomised by the International Accounting Standards Board, other entities have also entered the field including the United Nations through the Principles of Responsible Investment (UN PRI) and the OECD. These types of organisations can claim both legitimacy and authority if not the coercive powers of regulatory agency.

Academic research in the media spotlight: if often-times also sponsored by large investment houses and consulting groups, academic research has also played a role in clarifying the issues as regards to the cost effectiveness of investment management. There is a veritable industry in disciplines as diverse as finance, economic geography, and sociology focused upon the structure and performance of the investment management industry. Often-times obscure in terms of the nature of problems tackled and the results produced, some media groups have played crucial roles in translating this research into bite-sized chunks relevant to the industry as a whole as well as its decision-makers. The Financial Times has been particularly effective in bridging these two very different worlds.

Crises and their post-mortems: the Asian financial crisis of 1997, the implosion of Long Term Capital Management, the bursting of the TMT bubble, and the global financial crisis precipitated by the failure of leading banks and instruments of securitisation, have all been important for clarifying industry-wide expectations as to the nature of market behaviour and prospects for the future. Not only is there a vibrant market for accounts of the events leading up to these crises, systematic accounts of institutional failure, and the documentation of perverse and self-defeating behaviour, these stories play a crucial role in organising industry and government responses to their immediate consequences and long-term implications.

Government inquiries and reports: if largely backwards looking in impulse, and about allocating blame especially if the government sponsor seeks to find fault in previous governments' policies, these events can provide contemporaneous strategies of community-building, a stage for setting the agenda for the future. Even if neither the Wilson Report of 1980 nor the Myners Report of 2001 made a substantial difference to the problem posed, they did articulate the issues for at least the following decade. Might the same fate awaits the Kay Report on UK equity markets initiated by the Secretary of State for Business Innovation \& Skills (June 2011)? Its explicit reference to "asset owners' long term objectives" and the UK Stewardship Code provides an opportunity for a reconceptualisation of the logic of fiduciary duty in the context of recent authoritative studies on the costs of market short-termism (see Haldane and Davies 2011 and OECD 2011b). 
These are just six mechanisms for organising and institutionalising communities of practice. Some are more formal than others and some have greater innovative potential than others if judged against the unresolved issues made apparent by recent financial crises. One obvious issue associated with the inherited norms and conventions of investment management is the cost of short-term market trading; notwithstanding the widespread adoption by institutional investors of strategic asset allocation, many of their service providers churn their assets under management seeking to meet quarter-to-quarter benchmark targets. At one level, this is a problem of governance-setting incentives consistent with long-term investment goals and objectives. At another level, however, it is a problem of convention-breaking with the contractual norms that govern service contracts across the entire industry.

\section{Conclusions}

The virtue of the common law was to be found in its permissive framework for private action. Based upon coherent and self-referencing 'communities of practice' it was supposed to be an adaptive 'regulatory' mechanism consistent with the promotion of social welfare. As such, it can be seen to resonate with recent arguments to the effect that financial markets are best seen as ecologies of adaptive behaviour subject to changing norms and conventions (in contradiction to the efficient market hypothesis; see Lo 2004). In fact, the argument presented in this paper suggests that fiduciary duty is an historical anachronism without firm foundations in the contemporary world. If there were 'communities of practice' with the authority to set and maintain norms and conventions, this does not seem to be a plausible characterisation of the second half of the 20th century or the first decade of the 21st century. Indeed, the evidence suggests that 'communities of practice' are more likely associated with the subversion of beneficiaries' interests than with social welfare.

Recognising the problems associated with the common law, statute has "superseded" this institution with the promise of comprehensive frameworks for social problems (Posner 1990, 252). Statutes are thought more appropriate to the complex world of modern economies, overlapping interests and economic processes, and the never-ending quest for power and influence over the variables that affect economic growth. They are, as well, blueprints or solutions to problems which go well beyond the immediate interests of private agents. But, notwithstanding the optimism associated with the passage of legislation and the establishment of regulatory agencies, it is arguable that statute is as much defensive and reactive as it is forward-looking. So, for example, the passage of legislation in 
the UK designed to underwrite workplace pensions over the past 20 years can be read as reactions to apparent problems of pension fund governance.

Basically, legislation was deemed necessary because the golden rule of fiduciary duty was obviously inadequate as the instrument for 'regulating' pension fund decision-making. In this paper, I suggested that this is because 'communities of practice' have lost their legitimacy and authority. Equally, it is arguable that statute was necessary because pension funds are actually financial institutions not just decision frameworks, embodying interests and claims for representation that transcend simpleminded recipes for decision-making based upon fiduciary duty. This point was illustrated by reference to the nature and effects of the codes of practice introduced by the UK Pensions Regulator. Whereas fiduciary duty would have it that beneficiary interest is the touchstone of decision-making, through statute the UK government has sought to 'balance' the interests of beneficiaries with the interests of the government, the employer, and society at large through best practice models of pension fund governance.

Government intervention in the relationship between pension fund trustees and beneficiaries was prompted, in part, by a larger concern about the status quo bias apparent in UK pension fund investment decision-making. The Myners Report was highly critical of UK pension fund trustee skills and expertise, and derided inherited norms and conventions that govern the investment decisionmaking process. For Myners, the issue was about the lack of pension fund investment at the frontiers of economic innovation. Curiously, however, the government sidestepped the issue relying upon the common law principle of fiduciary duty to set the framework for asset allocation and investment management. Here, as in many other Anglo-American countries, government was unwilling to set priorities for pension fund investment, enumerate permitted investments, or use a quantitative formula for asset allocation. Perhaps the government was conscious of the political firestorm occasioned by previous attempts to set the investment agenda for UK pension funds.

Equally curious is the implied reliance of government upon attempts by the pensions and insurance sector as well as the financial services industry to set the agenda on new approaches to long-term investment. As suggested in the previous section, various strategies have been deployed so as to organise various interests into 'communities of practice' around the related topics of responsible investment, sustainability, long-term investment and the ongoing transformation of the global economy. At base, government assumes that well-intentioned agents, conscious of the long-term interests of beneficiaries and responsive to the duties of care associated with the notion of fiduciary 
duty, are better placed to promote long-term innovation than its regulatory agencies. Perhaps this is true. But it is remarkable that these assumptions should be accepted without debate, given recent experience of self-interested agents who brought the global financial system to its knees. On this issue, government has accepted the Greenspan fallacy notwithstanding evidence to the contrary.

Paradoxically, the promotion of innovation in long-term investment relies heavily upon a social commitment to the common law principle of fiduciary duty and its associated 'communities of practice' otherwise rejected by government in its regulation of pension fund governance. Worse, perhaps, is the fact that the interpretation of fiduciary duty has been captured by interests largely antagonistic to innovation in investment management. In so many ways, fiduciary duty has been so denuded by government regulation that what is left is a rhetorical gesture on behalf of those that stand to benefit by the status quo. At best, fiduciary duty remains as a case specific mechanism for restitution in circumstances where government policy, regulation, and its guarantee institutions are either not relevant or unable to deal with the issue. At worst, fiduciary duty remains as a trump card for those that would wish to protect their own interests in the face of obvious demands for profound change in the nature of investment practice.

\section{References}

Aalberts, R. J. and Poon, P. S. 1996. The new prudent investor rule and the modern portfolio theory: a new direction for fiduciaries. American Business Law Journal 34: 39-71.

American Law Institute. 1992. Restatement (Third) of Trusts: Prudent Investor Rule. St. Paul, Minn.: American Law Institute Publishers.

Atiyah, P. S. 1995. An Introduction to the Law of Contract. Oxford: Oxford University Press.

Berry, C. 2011. Protecting our Best Interests: Rediscovering Fiduciary Obligation. London: Fair Pensions.

Bix, B. 1993. Law, Language, and legal Determinacy. Oxford: Clarendon Press.

Braithwaite, J. 1989. Crime, Shame, and Reintegration. Cambridge: Cambridge University Press.

Capie, F. 2011. The Bank of England: 1950s to 1979. Cambridge: Cambridge University Press.

Calabresi, G. 1982. A Common Law for the Age of Statutes. Cambridge, MA: Harvard University Press.

Clark, G. L. 1985. Judges and the Cities: Interpreting Local Autonomy. Chicago: University of Chicago Press.

Clark, G. L. 2000. Pension Fund Capitalism. Oxford: Oxford University Press. 
Clark, G. L. 2006. Regulation of pension fund governance. In The Oxford handbook of Pensions and Retirement Income, edited by G. L. Clark, A. Munnell, and M. Orzsag. Oxford: Oxford University Press, pp. 483-500.

Clark, G. L. 2007. Expertise and representation in financial institutions: UK legislation on pension fund governance and US regulation of the mutual fund industry. Contemporary Social Science 2: 1-23.

Clark, G. L. 2011. Myopia. Dialogues in Human Geography 1: 4-27.

Clark, G. L. and Urwin, R. 2008. Best-practice investment management. Journal of Asset Management 9(1):2-21.

Coleman, J. 2001. The Practice of Principle: In Defence of a Pragmatic Approach to Legal Theory. Oxford: Oxford University Press.

Dale, R. 2004. The First Crash: Lessons from the South Sea Bubble. Princeton: Princeton University Press.

Dworkin, R. 1978. Taking Rights Seriously. London: Duckworth.

Dworkin, R. 2011. Justice for Hedgehogs. Cambridge MA: Harvard University Press.

Epstein, R. A. 1995. Simple Rules for a Complex World. Cambridge, MA: Harvard University Press.

Fish, S. 1980. Is There a Text in this Class? Cambridge, MA: Harvard University Press.

Freshfields Bruckhaus Deringer. 2005. A Legal Framework for the Integration of Environmental, Social and Governance Issues into Institutional Investment. London.

Fried, C. 1981. Contract as Promise: A Theory of Contractual Obligation. Cambridge: Harvard University Press.

Friedman, L. M. 1964. The dynastic trust. Yale Law Journal 73: 547-92.

Hacking, I. 1990. The Taming of Chance. Cambridge: Cambridge University Press.

Haldane, A. G. and Davies, R. 2011. The short long. London: Bank of England.

Hart, H. L. A. 1961. The Concept of Law. Oxford: Clarendon Press.

Hawley, J. P., Johnson, K., and Waitzer, E. 2011. Reclaiming fiduciary duty balance. Rotman International Journal of Pension Management 4(2):4-16.

Hawley, J. P. and Williams, A. T. 2001. The Rise of Fiduciary Capitalism: How Institutional Investors can make America More Democratic. Philadelphia: University of Pennsylvania Press.

HM Government. [Wilson Report]. 1980. Committee to Review the Functioning of Financial Institutions: Report. Cmnd. 7937. London: HMSO.

HM Government. [Goode Report]. 1993. Pension Law Reform. CM2342-I. London: HMSO. 
HM Government. 2001. Mirror Group Newspapers plc: Report by the Honourable Sir Roger John Laugharne Thomas and Raymond Thomas Turner. London: Department of Trade and Industry.

HM Government. 2006. Trusting in the Pensions Promise: Government Bodies and the Security of Final Salary Occupational Pensions. HC 984. London: The Stationery Office.

King, R. and Levine, R. 1993a. Finance and growth: Schumpeter might be right. Quarterly Journal of Economics 108: 717-37.

King, R. and Levine, R. 1993b. Finance, entrepreneurship and growth: theory and evidence. Journal of Monetary Economics 32: 513-42.

Knight, E. R. W. 2010. The economic geography of European carbon market trading. Journal of Economic Geography doi: 10.1093/jeg/lbq027.

La Porta, R., Lopez-de-Silanes, F., Shleifer, A., and Vishny, R. 1997. Legal determinants of external finance. Journal of Finance 52: 1131-50.

La Porta, R., Lopez-de-Silanes, F., Shleifer, A., and Vishny, R. 1998. Law and finance. Journal of Political Economy 106: 1113-55.

Langbein, J. H. 1997. The secret life of the trust: the trust as an instrument of commerce. Yale Law Journal 107: 165-89.

Langbein, J. H. 2005. Questioning the trust law duty of loyalty: sole interest or best interest? Yale Law Journal 114: 929-90.

Langbein, J. H. 2007. Why did trust law become statute law in the United States? University of Alabama Law Review 58: 1096-82.

Langbein, J. H. and Posner, R. A. 1976. The revolution in trust investment law. American Bar Association Journal 62: 887-91.

Lewis, D. 1969. Convention: A Philosophical Study. Cambridge, MA: Harvard University press.

Lo, A. 2004. The adaptive markets hypothesis: market efficiency from an evolutionary perspective. Journal of Portfolio Management 30: 15-29.

Maitland, F. W. [1905] 2003. State, Trust and Corporation, edited by D. Runciman and M. Ryan. Cambridge: Cambridge University Press.

Merton, R. and Bodie, Z. 2005. The design of financial systems: towards a synthesis of function and structure. Journal of Investment Management 3: 1-23.

Myners Report. 2001. Institutional Investment in the United Kingdom: A Review. London: HM Treasury.

Organisation for Economic Cooperation and Development. 2011a. Survey of Investment Regulation of Pension Funds. Paris. 
Organisation for Economic Cooperation and Development. 2011b. Promoting Long-Term Investment by Institutional Investors: Selected Issues and Policies. Paris.

Peston, M. 1980. The Wilson report. Political Quarterly 51: 481-84.

Pettit, P. 2002. Rules, Reasons, and Norms. Oxford: Oxford University Press.

Posner, R. A. 1990. The Problems of Jurisprudence. Cambridge MA: Harvard University Press.

Richardson, B. J. 2008. Socially Responsible Investment Law: Regulating the Unseen Polluters. Oxford: Oxford University Press.

Richardson, B. J. 2011. From fiduciary duties to fiduciary relationships for socially responsible investing: responding to the will of beneficiaries. Journal of Sustainable Finance \& Investment 1(1): 5-19.

Roe, M. J. 2006. Legal origins, politics, and stock markets. Harvard Law Review 120: 460-527.

Rosenburgh, M. and Spieler, A. C. 2009. $21^{\text {st }}$ century pensions: the risk, the hedge and the duty to consider. The Journal of International Business Law xx: 45-61.

Runciman, D. 2008. Political Hypocrisy: The Mask of Power, from Hobbes to Orwell and Beyond. Princeton: Princeton University Press.

Schanzenbach, M. and Sitkoff, R. H. 2007. Did reform of prudent trust investment laws change trust portfolio allocation? Journal of Law and Economics 50: 681-711.

Shiller, R. J. 2000. Irrational Exuberance. Princeton: Princeton University Press.

Shiller, R. J. 2002. Bubbles, human judgement, and expert opinion. Financial Analysts Journal 58(3): 18-26.

Stapleton. G. P. 1996. Institutional Shareholders and Corporate Governance. Oxford: Oxford University Press.

Stone, E. G. 1994. Must we teach abstinence? Pensions' relationship investments and the lessons of fiduciary duty. Columbia Law Review 94: 2222-66.

Surowiecki, J. 2004. The Wisdom of Crowds. New York: Random House.

Thomas, G. and Hudson, A. 2004. The Law of Trusts. Oxford: Oxford University Press.

Thornton, R. 2008. Ethical investments: a case of disjoined thinking. Cambridge Law Journal 67: 396422.

Trebilcock, M. J. 1993. The Limits of Freedom of Contract. Cambridge: Harvard University Press.

Wittgenstein, L. 1968. Philosophical Investigations. $3^{\text {rd }}$ Edn. London: Macmillan.

Woods, C. 2011. Intergenerational equity and sustainable investment. DPhil Thesis: University of Oxford. 
Woods, C. and Urwin, R. 2010. Putting sustainable investing into practice. Journal of Business Ethics 92(supplement): 1-19. 